Hungarian Educational Research

Journal

\title{
Knowledge Brokers in the Heart of Europe: International Student and Faculty Mobility in Hungarian Higher Education
}

\author{
Gabriella Pusztai16 , Ilona Dóra Fekete ${ }^{17,}$ \\ Ágnes Réka Dusa ${ }^{18}$, Eszter Varga ${ }^{19}$ \\ Abstract
}

Until the late 1980s a Soviet-type interpretation of internationalization was used in Hungary, which isolated countries of the communist bloc within the Iron Curtain. In 1993, after the democratic transformation, a new Higher Education Act was passed. Although the first democratic government started to replace the old type of higher education policy with a European one, the internationalization process progressed slowly. Hungarian education policy puts a special emphasis on internationalization strategies based mainly on the encouragement of individual mobility. However, the socio-economic disadvantages of Hungarian population compared to Western Europeans reduce the efficiency of these endeavors. This paper describes four aspects of higher education internationalization in Hungary drawing from a review of prior research and analysis of survey data: 1) the political and institutional context of higher education internationalization in Hungary; 2) the mobility of Hungarian faculty and researchers; 3) the outbound mobility of Hungarian students; and 4) incoming student mobility to Hungarian universities. Our paper is a significant contribution to the literature, because (1) we use the actorcentered approach of internationalization (2) we not only analyze national and international statistics, but also we drew our conclusions from original survey data, that is we are able to summarize the individual motives and obstacles as well.

Keywords: higher education, international education, universities, student mobility, faculty mobility, Hungary

\footnotetext{
${ }^{16}$ Gabriella Pusztai, University of Debrecen, Debrecen (Hungary), pusztai.gabriella@arts.unideb.hu

17 Ilona Dóra Fekete, Eszterházy Károly University of Applied Sciences, Eger (Hungary), feketeilona@ektf.hu

18 Ágnes Réka Dusa, University of Debrecen, Debrecen (Hungary), agnesdusa@gmail.com

${ }^{19}$ Eszter Varga, University of Debrecen, Debrecen (Hungary), varga.eszter86@gmail.com
} 


\section{An Overview of Higher Education in Hungary}

Before the political transition in 1989, the socialist model of higher education was at work in Hungary. State interest came first before academic or market concerns. Participation in higher education was not influenced by student or labor market demands, as labor-force production was planned and controlled by the state and tertiary enrollment numbers were regulated by the use of admission quotas. During the last two decades of the socialist era, students from elite families were admitted to the limited number of higher educational posts. Reflecting political and ideological priorities, quotas were set up to admit students from the working class and other state-preferred groups. Only about onetenth of Hungarian high school graduates participated in higher education prior to transition.

After 1989, the state abandoned these restrictive higher education policies and the first wave of tertiary education expansion followed almost immediately. At the turn of the millennium, partially as a result of the demographic wave, multitudes of youth entered the Hungarian higher education system. As a consequence of the expansion, institutions increased their capacity, new campuses were built, and the faculty was overloaded with high course load and high student/faculty ratio.

The democratic, law-regulated model abolished the monopoly of the state as a maintainer of higher education. In 2014, of the nation's 66 higher education institutions, 28 are public universities and colleges, 25 are church-run, and 13 are run by private foundations. Most $(87.5 \%)$ students are studying in state universities, 6.5\% in church-maintained, and 6\% in private institutions. In the middle of the 2000s, after the rapid expansion, the demographic downturn started in the 18-25 cohort (Statistical Yearbook of Education, 2014). In 2015, 306,000 students were enrolled in bachelor and master's degree programs in Hungary, of which 217,000 were enrolled in full-time training, and another 14,000 in two-year undergraduate programs.

Free market principles of effectiveness, free competition between institutions, quality assurance, introduction of tuition fees to limit overconsumption, and involvement of private investors gained political traction in Hungary in the 1990s. After the fall of the Iron Curtain, the concept of the welfare state in Europe was on the verge of crisis. The concept of the retreating state was brought into Hungary by Hungarian researchers, lecturers and students who studied or worked in the US and UK with scholarships, including current Prime Minister Viktor Orbán, who studied abroad in Oxford with a scholarship received from the Soros Foundation (Kávássy, 2009). While the application of free market principles to education in general, and to higher education in particular, 
gained political traction in Hungary in the 1990s and early 2000s, some groups of Hungarian intellectuals started to oppose the neoliberal principles after the crisis in 2008 (Pusztai, 2003).

After the political transformation in 1989, many Hungarian academics were looking for financial support from the west in several fields. The previously (forcibly) dominant ties with academics from Eastern Europe were no longer perceived to be important and were cut. Only much later did academic cooperation with Hungary's eastern neighbors come to the center of attention, when the "glamour" of the free western world wore off (Fekete, 2008). Hungary, which had been at the western periphery of Soviet influence, became the eastern border of the European Union after joining it in 2004. Membership in the European Union had a great influence on academic cooperation as well as on the formation of new academic networks among higher educational institutions (Kozma, 2004). The Central and Eastern European Region (CEE) became a kind of mediator between academics in the east and west.

The import of western ideas and practices to Hungarian higher education is not without challenges, due to the many prevailing, Soviet-influenced characteristics of Hungarian higher education institutions (Weber \& Liikanen, 2001; Polyzoi \& Cerna, 2001). For example, the higher education system inherited from Soviet times is characterized by the duality of degrees and ranks in universities and so-called academies of sciences. The hierarchy within the academic community manifests itself in academic degrees, which stand parallel to or even independently from, and sometimes not even harmonizing with, the university ranks (Kozma, 2004). Specific ranks may indicate both institutional status and academic advancement, and old terms used prior to 1989 co-exist with new ones (Fináncz, 2009). To make things even more complicated, the Hungarian higher education system is subdivided into the university sector and the college sector, and lecturers and researchers have to meet different requirements for academic advancement depending on the sector in which they are employed.

The first steps of higher education internationalization in Hungary started a decade into transition. In 1999 Hungary was among the countries signing the Bologna Declaration, and the Hungarian government undertook the establishment of a higher education system based on two major cycles. Currently, the system has four levels. Doctoral studies (PhD) were introduced in 1994 (ISCED 6 level) following the enactment of the Higher Education Act in 1993. Advanced vocational programs (ISCED level 5B) were introduced in 1997. The launch of three-year bachelor degree programs became possible in 2004 with the modification of the Higher Education Act of 2003. The multi-cycle system of higher education was fully implemented by 2006 (Pusztai \& Szabó, 2008; Pusztai, 2015). 
Another important development in Hungarian higher education policy post-1989 was the introduction of the European Credit Transfer System (ECTS) in 2002, which was the result of a long process and was aimed at making the Hungarian higher education system 'Eurocompatible.' Since 1990, there have been institutional attempts to restructure the student assessment system and introduce an assessment system based on credit accumulation. The introduction of ECTS on a legal level appeared with the modification of the Higher Education Act of 1996, and it became compulsory for all institutions beginning in 2002. The so-called "diploma supplements," introduced in 2003, were aimed at improving the transferability of credits and higher education credentials across national borders (Pusztai \& Szabó, 2008; Pusztai, 2015). After 2010, the government established technology-transfer offices and international affair offices at Hungarian universities and created academic departments at the most prestigious universities in the country specifically with the intent to facilitate international academic collaboration.

\section{Guiding Perspectives, Research Questions, and Data Sources}

Jane Knight's article (2004) defines the use of the concept of internationalization in academic works and differentiates between the bottom-up (institutional) and top-down (national/sector) approaches of internationalization. It also emphasizes that it is so complex that there cannot be one universal definition used for it. Our approach is specifically actor- and activity-centered. In countries belonging to the former Soviet bloc, internationalization was a liked slogan, however, it had its own unique and formal meaning. Institutional relations between countries within the Soviet bloc were possible with the approval and control of the Soviets, and the relations could only be strictly formal. Following the political changes, bringing in the new understanding of internationalization meant getting rid of the former highly formal internationalization concept, and the possibility to act was shifted from the institutional to the individual level. This relationship is most clearly represented in mobility - regardless of whether the goal of mobility was learning, teaching or research -, because it helped the individuals to create their own international and comparative views, which is one of the crucial results of internationalization that appears through the global flow of technology, economy, knowledge, people, values and ideas across borders. The official policy, funding, programs, and regulatory frameworks are only a formal layer of it; the countries of today show a convergent progress in this, while displaying significant differences in social action.

For the purposes of this paper, we define internationalization as the spatial mobility of individuals and the transmission of information, views, behavioral patterns, and everyday practices, and the effects of these activities, on local cultures. We shift from considering internationalization as a political, organizational topic to considering it as a sociological 
question. Simmel (1922) describes the concept of social actors, or "brokers," who are positioned to negotiate between two groups and allow or enhance resource flows between otherwise unconnected or only weakly connected actors. Based on their strategic position in social networks, these actors, while their activities result in various changes in the groups, could be mediators, arbitrators or tertius gaudens. The classification is based on whether the act of brokerage is to the advantage of the community as a whole or only to the social actors themselves (Simmel, 1922). A knowledge broker is an individual who participates and contributes in multiple communities to develop relationships and networks between producers and users of knowledge, facilitates knowledge transfer, initiates the common construction of new knowledge, and supports changes (Kakihara \& Sorensen, 2002; Meyer, 2010; Sverrisson, 2001).

Cosmopolitan behavior is a type of orientation described by Merton (1968) that we use to characterize the activities of knowledge brokers. "Cosmopolitan" individuals habitually consider themselves to be a part of the global society. They tend to use more diverse media to collect globally valid information and they may leave their homeland to join the society of the global labor market and cosmopolitan community. In contrast, "local" individuals define themselves with respect to their own local community and they highly value local friendships and close connections. Findings from prior research suggest that the impact of knowledge brokers who mediate between social networks may increase with the extent of the gap that they are able to bridge with their mediating activity; the larger the gap between social networks, the greater the amount of social capital brokers may be able to create (Burt, 2000).

The emergence of individual knowledge brokers (Baruffaldi \& Landoni, 2012; Lightowler \& Knight, 2013) played an important role in preparation of the political transformation (1989-1990) in post-socialist countries. Despite anecdotal evidence of the role of knowledge brokers in the political and economic transition of Hungary post-1989, prior research has paid little attention to the role of knowledge brokerage in the spreading of higher education internationalization. To understand the deep structures of internationalization, we have to analyze more thoroughly the activities of knowledge brokers and their impact, and assess the potential benefits and drawbacks of knowledge brokerage for communities. In this paper, we study the internationalization of Hungarian higher education by identifying individual actors that mediated between the local (Hungarian) context and outside forces. We focus on two groups of international knowledge brokers: internationally mobile faculty and internationally mobile students.

To gauge faculty mobility, we explored patterns of academic cooperation appearing in the Hungarian higher education system, drawing on data from interviews with 20 Hungarian 
experts of the field. The interviews were conducted and recorded by the Hungarian Academy of Sciences' Sociological Research Group for Organization and Work and were analyzed by the Centre for Higher Education Research and Development (CHERD) at the University of Debrecen. Further data were collected between 2009 and 2012 from a research study carried out in the Partium international higher education region, which is located at the border region of three countries: Hungary, Romania, and Ukraine. We investigated the mobility of faculty and students in the five higher education institutions located in the Partium region; two of the five institutions are church-maintained. Our analysis of faculty mobility is based on institutional records at these five institutions. The international networks of Hungarian faculty were examined at two faculties: one located at a prestigious research university and the other at a college of applied sciences. More than 200 faculty members $(n=210)$ responded to our survey, out of the whole body of approximately 750 faculty members employed at these two faculties. Our sample was stratified by field of science.

The data on internationally mobile Hungarian students come from surveys conducted by CHERD staff between 2008 and 2014. The survey, which CHERD repeats every two years, is carried out among students at a prominent Hungarian university and two colleges of applied sciences. The sample was stratified, multi-stage and clustered. Since the survey aims to be representative of the entire student body at each of these three higher education institutions, we randomly selected a course from each faculty, and invited all students enrolled in the randomly selected course to participate in the survey. The number of students responding to the survey varies across years and degree program types: 1,009 students who were enrolled in a BA or BSc degree program in 2008; 485 students who were enrolled in a MA/MSc degree program in 2010; 1,270 BA/BSc or MA/MSc students in 2012; and 1,198 BA/Bsc and MA/Msc students in 2014. Information on the number of incoming international students is based on institutional records at the University of Debrecen from the years 2014 and 2015. Findings pertaining to the experiences of international students studying at the University of Debrecen are based on in-depth, educational life interviews with three international students from South Korea who were identified using the snowball method.

\section{Patterns of International Mobility in Hungarian Higher Education}

\section{Hungarian Students' Participation in International Mobility}

Higher education institutions in Eastern European countries were eager to build connections with other European institutions through student mobility in the 1990s (Kasza, 2010). International associations that represent higher education institutions across Europe, such as the International Association of Universities, Conference des Recteurs Européens, and the Academic Cooperation Association, facilitated this process 
(Hrubos, 2005). In addition to initiatives at the institutional level, and like other former Soviet and Eastern bloc nations (Perna, Orosz, \& Jumakulov, 2015), the government of Hungary also established scholarship programs to develop human capital. The Hungarian Scholarship Board Office was established in 1991 to coordinate student mobility and in 2004 a government decision called for the promotion of student mobility for the sake of the establishment of the European Higher Education Area (EHEA).

Despite governmental and institutional efforts to increase the mobility of Hungarian students, little is known about the extent and characteristics of international student mobility in Hungary. Publicly available data on outbound student mobility only capture short-term credit-mobility (that is, semester abroad). No data are systematically collected about degree-mobility, that is, the extent to which students go abroad with the intention to get a university degree. We discuss Hungarian students' participation in international mobility with this limitation.

In 2004, only $2 \%$ of Hungarian students studied abroad, a considerably lower percentage than the European Union average (Tót, 2005). The low rate of study abroad participation was likely due to the fact that Hungarian study abroad scholarships cover only $40 \%$ of the living costs abroad, and the Hungarian minimum wage is too low to allow the majority of parents to supply the missing amount (Tót, 2005). Other studies also found that outbound student mobility is low in Hungary (Dusa, 2015a, 2015b; Kasza, 2010). Hungarian university students who responded to a survey reported to be motivated to study abroad but perceived that they cannot afford it financially; another common reason for not participating in study abroad was the students' self-assessment that they cannot speak a foreign language well enough (Kasza, 2010, Dusa, 2015a, 2015b).

Changes in the number of Hungarian students who studied abroad in the framework of the Erasmus mobility scheme suggests that the short-term outbound mobility of Hungarian students is increasing. Study abroad, as measured by participation in the Erasmus mobility program, doubled from 1998 to 1999 and has increased nearly sevenfold to 2014. According to the 2011/2012 edition of the Follow-up Survey of Hungarian University Graduates (Diplomás Pályakövető Rendszer, 2012), 10.7\% of all Hungarian university graduates studied at least a few months in a foreign country during their university years. We can trace some typical mobility channels by the most popular target countries. In Europe and worldwide, mobile students typically go from east to west and from south to north (Kasza, 2010; Langerné, 2009). Mirroring global student mobility trends, the most popular destinations of Hungarian mobile students are Western- and North-Western European countries. The most popular destination countries of Hungarian students are Germany, Austria, Great Britain, France, and Finland (Kasza, 2010; Langerné, 2009). 
Most Hungarian students who study abroad are from the traditional (five-year) training system and have a single university major (Kiss, 2014). The number of study abroad participants is lower among students enrolled in short-term (three-year) bachelor's degree programs, students enrolled at colleges (as opposed to universities), and students enrolled in correspondent training. Hungarian students studying humanities participate in Erasmus mobility programs at the highest rate (7.8\%). Humanities students enrolled in foreign language degree programs are the most likely to complement their Hungarian university education with semesters abroad. They are followed by those who study economics (participation rate in this group is 6.8\%) and social sciences (6\%). In contrast, only $2.5 \%$ of students in teacher education programs have studied abroad (Kiss, 2014). Data from other sources also suggest that the outbound mobility of Hungarian students varies greatly by field of study. Kasza (2010), relying on data from the Graduate Research 2010 survey, found that $39 \%$ of students participating in international student mobility study economics, $21.6 \%$ study humanities, $8.3 \%$ study law and administrative studies or engineering (also 8.3\%). Only 6.1\% of Hungarian students abroad are involved in medical or natural sciences, 3.8\% in IT technology, 3.4\% in agrarian majors and $2.3 \%$ in teacher education (Kasza, 2010). Variation in study abroad participation may be linked to differences in mobility plans across study fields. Only $16.4 \%$ of Hungarian students in teacher education programs reported to have plans to study abroad in the Eurostudent survey (Kiss, 2014). In comparison, 34\% of students who study medicine report that they would like to study abroad, although only $2.5 \%$ of them actually do so.

The majority of Hungarian students participating in short-term study abroad attended the biggest and most prestigious universities in Budapest (Eötvös Loránd University, Corvinus University of Budapest, and Budapest University of Technology and Economics), and big rural universities (such as the University of Pécs, the University of Szeged, and the University of Debrecen) send ever smaller quantities. Small rural colleges send the fewest number of students to study abroad (Kasza, 2010; Langerné, 2009).

In our research-series we examined the students of the higher educational institutions of the same region between 2003 and 2005. Thus we collected longitudinal results of experiences and plans regarding student mobility. While there is a moderate approach in connection with international study experiences, the proportion of those who plan mobility shows much more growth. It displays that the gap between the desire to be mobile and actually achieving it is bigger in the underdeveloped regions in the country. 
HERJ Hungarian Educational Research Journal Vol 6 (2016), No 1

Table 1. Mobilty and the plans for mobility among the students at Debrecen (2003-2015)

\begin{tabular}{|c|c|c|c|c|c|}
\hline & $\begin{array}{c}\text { Regional } \\
\text { University } \\
2003 \\
(\mathrm{~N}=1040) \\
\end{array}$ & $\begin{array}{c}\text { Regional } \\
\text { University } \\
2005 \\
(\mathrm{~N}=562) \\
\end{array}$ & $\begin{array}{l}\text { TERD }^{20} \\
2008 \\
(\mathrm{~N}=728)\end{array}$ & $\begin{array}{c}\text { TERD } \\
2010 \\
(\mathrm{~N}=439)\end{array}$ & $\begin{array}{c}\text { IESA }^{21} 2015 \\
(N=1062)\end{array}$ \\
\hline $\begin{array}{l}\text { Students' mobility } \\
\text { experience at University of } \\
\text { Debrecen }\end{array}$ & $5,1 \%$ & $9,3 \%$ & $8,1 \%$ & $9,1 \%$ & $8,8 \%$ \\
\hline $\begin{array}{l}\text { Students' mobility plans at } \\
\text { University of Debrecen }\end{array}$ & $7,6 \%$ & n.a. & n.a. & $35,8 \%$ & $28,1 \%$ \\
\hline
\end{tabular}

Based on our survey it is evident that the greatest supporters of the mobility of students coming from an underdeveloped region, are the parents' superior education, the objective and subjective financial situation, the type of settlement, as well as language knowledge, which is also dependant on social status. We wanted to examine the biggest obstacles as well, and we found these to be the following: the extra financial burden that come with mobility, insufficient foreign language knowledge, being far from family and friends, and also falling behind and the risk of losing credits (Dusa, 2015).

\section{Incoming Student Mobility}

While only 2,485 international students studied at Hungarian universities in the mid1980s, their number increased tenfold after the change of regime (Berács, Hubert, \& Nagy, 2009). Before the political and economic transition, foreign students arrived at Hungary through a variety of bilateral exchange programs that the Hungarian government supported. Bilateral student exchange programs typically covered neighboring socialist countries and a number of developing countries from Asia and Africa. While in Hungary, these foreign students could earn degrees in English or in German at a number of Hungarian universities.

Since the 1980s, the composition of incoming students has changed. In the academic year of 2007/2008, students from 118 countries were studying in Hungary; there were 24 countries with more than 100 students pursuing studies at Hungarian universities. In 2011/2012, the distribution of foreign students coming to Hungary by regions was as follows: Africa 3.6\%; Asia 20.8\%; America 3.4\%; and Europe 72.6\% (Berács et al., 2009). International students made up $5.6 \%$ of total university enrollment in Hungary in 2011/2012. Most international students at Hungarian universities participate in shortterm study abroad programs; only $7.1 \%$ of incoming students pursue a degree. About half

\footnotetext{
20 TERD - The Impact of Tertiary Education on Regional Development

21 IESA - Institutional Effects on Student Achievement in Higher Education
} 
(54\%) of all international students in Hungary in 2007/2008 were coming from neighboring countries. Many of these students were ethnic Hungarian students hailing from the border regions. These students were typically enrolled in degree programs taught in Hungarian. In other words, about half of the international students in Hungary at the time were "quasi" international (Berács et al., 2009).

Within Europe, the largest sending countries of international students to Hungary are Germany, Norway, and Sweden (Fekete et al., 2014). ${ }^{22}$ Outside Europe, other countries that send the largest number of students to Hungary include Iran, Israel, and Turkey. Among the Asian countries, Vietnam leads, perhaps due to the fact that during the socialist era, Hungary established a student exchange program with this country. Other sending nations from this region include China, Japan, and South Korea. Several diplomatic relations and initiatives have been established with Asian countries in recent years, which may partially explain the modest growth in Asian students studying in Hungary in recent years. Interestingly, the number of students in Hungary from South Korea and Saudi Arabia has doubled in the past two years (Fekete et al., 2014). This growth is likely the result of changes in the domestic higher education systems of these nations (Fekete et al., 2014).

Most international students enroll in the undivided medical training programs. The concentration of incoming students at medical training programs is not surprising; Hungarian universities boast medical faculties that are renowned internationally. Only Belgium and Spain have similarly high proportions of popular medical courses (Organisation for Economic Co-operation and Development, 2013; Szemerszki, 2005). In addition, Hungary hosts a high number of international students studying in agricultural departments compared to the European Union average (OECD, 2013). Descriptive statistics about the international student population of the University of Debrecen mirror international student enrollment patterns nationwide. In the 2014/2015 academic year, the number of international students enrolled at the university was 3,801, which is the largest number of international students at a single university in Hungary (University of Debrecen, 2014). This group of international students came from 89 different countries. The most students came from Nigeria (576), Iran (205), Israel (249) Vietnam (124), China (118), the United Kingdom (177), Turkey (189), and Brazil (143), not counting "quasi" international students from the neighboring countries of Romania, Ukraine, and Slovakia (University of Debrecen, 2014).

An exploratory study by one of the authors of this paper focused on the perceptions and experiences of three international students from South Korea who studied general

22 The ranking only includes countries that send more than 100 students to Hungary. 
medicine at the Medical and Health Science Center of the University of Debrecen. The author found that these international students perceived studying in Hungary as a starting point for their global mobility, and specifically as a potential entry point to American medical education. Studying in Hungary was seen as the starting point in their process of "global capital accumulation" (Kim, 2011). Our surveys and interviews show that students choose Debrecen University because compared to international schools, it offers affordable high quality and acknowledged diplomas, as well as an environment that is learner oriented and relaxed. It is proven that this piece of information is passed down through the cooperational networks of incoming students (Dusa, 2015; Varga, 2015).

\section{Incoming and outgoing faculty and researcher mobility}

Prior research has focused on the effects of higher education expansion on Hungarian faculty and the problems that occurred with the introduction of the multi-cycle training structure, but very little is known about Hungarian faculty members' academic networks and the ways that academic relationships, including international academic collaborations, are being formed (Fekete \& Simándi, 2013). A study focusing on churchmaintained higher education institutions in the Partium region found that the regional academic networks of university faculty were influenced by the church affiliation of the institutions where they worked (Fekete, 2008).

Although not focusing exclusively on higher education faculty, Viszt (2004) conducted a study at 45 Hungarian research centers, some of which were university-affiliated and others were maintained by the state or by private foundations. Viszt (2004) found that the destination nations of internationally mobile Hungarian researchers varied by academic discipline, and that researcher mobility was more common among individuals working in science and medicine than among researchers in other fields.

A potential explanation for higher rates of international mobility among Hungarian researchers working in the field of sciences and medicine may be related to a characteristic of faculty mobility in Hungary that pre-dates the transition. In a study based on interviews with leaders and experts of higher education, Pusztai (2007) found that prior to 1989 , certain fields of study were considered to be politically and ideologically "less dangerous," and lecturers and researchers in these fields experienced greater freedom when it came to travelling abroad and building international co-operational networks. The fields considered to be "less dangerous" corresponded, for the most part, to what Kyvik and Ingvild (1997) described as "hard" sciences, including medical and natural sciences.

The out-going instructor of the Erasmus teacher mobility program can choose from 31 countries - 27 EU members, 3 EFTA countries and Turkey. The research carried out by 
Rédei (2007) show that since 1997, when the program was launched, the number of participants tripled by 2007, and since then it has doubled (Rédei et al., 2007, Erasmus + annual report, 2014).

In our research we analyzed the data of out-going lecturers of a big research university and a regional college, which have plans to become university. Neither of them are in the capital, instead they are in a country town in the Eastern part of the country. Data shows that the number of incoming and out-going lecturers does not differ significantly, thus these institutions cannot be seen as obvious receiving or sending institutions. When the data from the research university and the regional college were compared we pointed out that though the absolute data seem to favour the big research university, the proportion of outgoing researchers is considerably higher in the regional college. Therefore it seems that the regional college can motivate their lecturers in gaining foreign experience better. Since in the regional college some hundred full-time lecturers are employed, in the big research university about one and half lecturers work. In the regional college there were $3 \%$ mobile workers in the beginning of the investigated period, but in the end of the era the proportion of mobile lecturers reached $10 \%$, while mobility proportion of the big research university were $3 \%$ and they doubled.

Figure 1. Out-going lecturers at the regional college and at the research university with Erasmus (2001-2014)

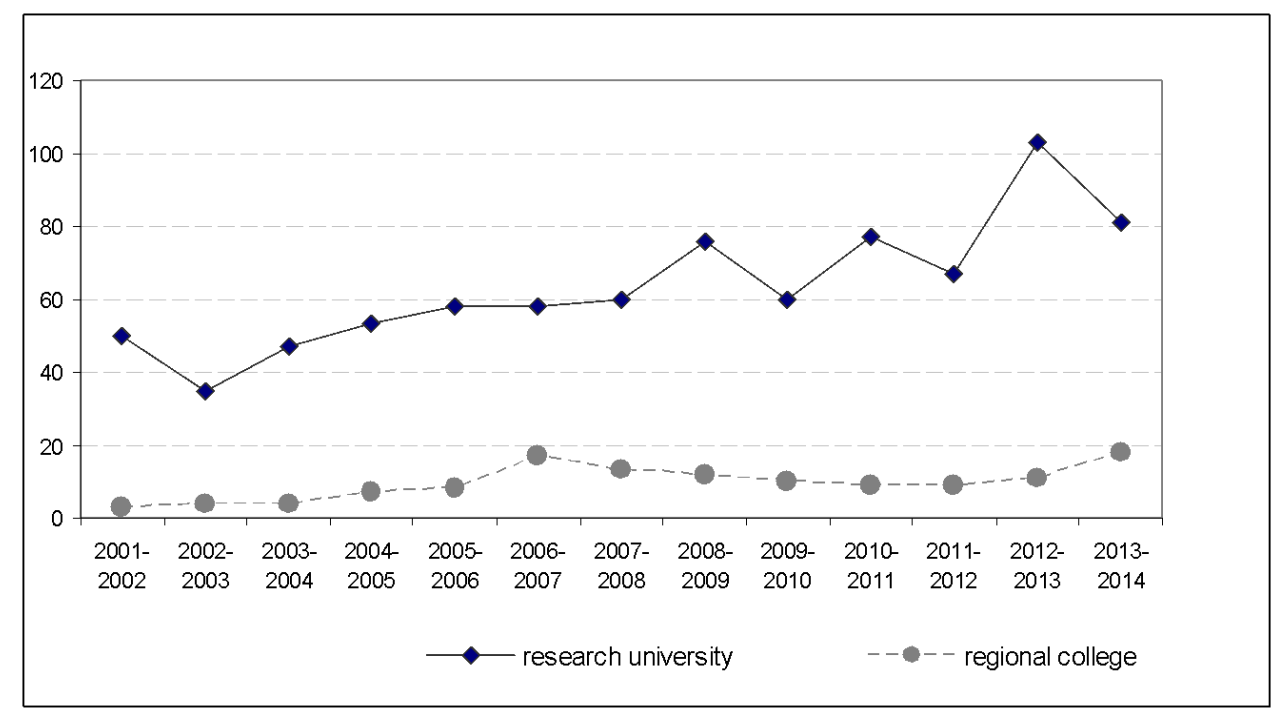

Source: International Relations Center at the University of Debrecen and at the Eszterházy Károly University of Applied Sciences

According to the data there are few knowledge brokers, and there is a lack of so called "cosmopolitan" researchers in the investigated higher education institutions. The majority of the lecturers are "local" individuals. Due to financial and organizational reasons few can afford to go abroad for a longer time. The roots of the problem are the 
lack of the sabbatical leave system, and the effect of a longer leave, which is dropping out from institutional social networks, that can lead to slower career. The financial side of the problem consists of limited resource for research mobility and difficulties in connection with arranging accommodation especially for researchers with families.

\section{Conclusion}

In this paper we documented the international mobility patterns of Hungarian students and faculty, as well as the mobility patterns of international students enrolled at Hungarian universities. According to our research experience internationally mobile students and faculty can be thought of as knowledge brokers, or nodes of international networks affiliated with higher education institutions who serve as pioneers for international co-operations, mediators of new research methods and research results. Knowledge brokers may encourage and support their colleagues and peers by distributing essential information, setting examples, and composing possible pathways that others may also use. Hungarian scholars and students on long-term visits abroad may enhance publication and other career opportunities for their fellow citizen colleagues.

Very little is known about the extent to which any of these potential benefits were realized at Hungarian higher education institutions that either send students and faculty abroad or receive international students. A major challenge in expanding knowledge about the potential benefits and drawbacks of international student and faculty mobility in Hungary is a lack of systematically collected, nationally representative data system that tracks outgoing and incoming student and faculty characteristics, their experiences while studying or working abroad or in Hungary, and the individual and societal outcomes associated with international experiences. We performed regional surveys, and our results show that the two groups of international knowledge brokers, which are internationally mobile faculty and internationally mobile students proved to be a narrow stratum. We investigated the reasons behind this phenomenon, and we can state that they are either financial or organizational reasons.

\section{Acknowledgements}

We would like to acknowledge useful comments and help from our colleague Dr. Aisi Li. We are also grateful to Dr. Laura W. Perna and Kata Orosz, the editors of this special issue, for their helpful comments and suggestions.

\section{References}




\section{HERJ Hungarian Educational Research Journal Vol 6 (2016), No 1}

Baruffaldi, S. H- -Landoni P. 2012 Return mobility and scientific productivity of researchers working abroad: The role of home country linkages. Research Policy, 41, 9.1655-1665.

Berács, J., Hubert, J. \& Nagy, G. (2009). A nemzetköziesedés folyamata a magyar felsőoktatásban. [The Process of Internationalization in Hungarian higher education]. Bologna Füzetek 3. Kutatási beszámoló a TEMPUS Közalapítvány számára. Budapest: Nemzetközi Felsőoktatási Kutatások Központja, Budapesti Corvinus Egyetem.

Burt, Ronald S. (2000): The network structure of social capital. Research in Organisational Behavior, 22:345-423.

Diplomás Pályakövető Rendszer (2012). DPR 2011-2012. Retrieved from http://uninke.hu/uploads/media_items/vegzett-hallgatok-elemzese-a-kozponti-kerdoiv-alapjan1.original.pdf

Dusa, Á. R. (2015a). A nemzetközi hallgatói mobilitás értelmezése eredményességi szempontból [An assessment of international student mobility in terms of achievement]. In: Pusztai, G., Kovács, K. (Eds.), Ki eredményes a felsőoktatásban? Oradea (Romania): Partium Press. (Who Is Successful in Higher Education? Hungarian)

Dusa, Á. R. (2015b). Pedagógushallgatók nemzetközi mobilitási tervei [International mobility plans of students in teacher training]. In: Pusztai, G., \& Ceglédi, T. (Eds.), Szakmai szocializácó a felsőoktatásban. Oradea (Romania): Partium Press. (Professional Socialisation in Higher Education. Hungarian)

Fekete, I. D. (2008). Networks and cooperation of public and church maintained higher educational institutions in Hungary. In: Pusztai, G. (Ed.), Religion and Values in Education in Central and Eastern Europe. Debrecen: CHERD Centre for Higher Education Research and Development.

Fekete, I. D., \& Simándi, Sz. (2013). International academic relations in Central and Eastern Europe: A brief comparative approach. In: Juhász, E. (Ed.), Education in Transition. Váhom (Slovakia): Dubnicky Technologicky Institute

Fekete, Zs., Kisbáró, E., Mester-Takács, T. \& Mészáros, G. (Eds.) (2014). A felsőoktatási mobilitást akadályozó és ösztönző tényezők Magyarországon [Factors encouraging and discouraging higher education mobility]. Komárom: Tempus Közalapítvány

Fináncz, J. (2008). Tudományos utánpótlásképzés Európában és Magyarországon: A doktori képzésben résztvevők helyzete. [Training the new supply of scientists in Europe and Hungary: The status of participants of doctoral programs.] (Unpublished doctoral dissertation.) Debrecen: University of Debrecen, Hungary

Hrubos, I. (2005). A peregrinációtól az európai felsőoktatási térségig. [From peregrination to the European Higher Educational Area.] Educatio , 14(2), 223-243.

Kakihara, M., \& Sorensen, C. (2002). “Post-modern” professionals' work and mobile technology. New ways of working in IS. Paper presented at the 25th Information Systems Research Seminar in Scandinavia, Copenhagen Business School, Frederiksberg, Denmark.

Kasza, G. (2010). Helyzetkép a nemzetközi hallgatói mobilitásról. [A snapshot of international student mobility.] In: Garai, O., Horváth T., Kiss L., Szép L. \& Veroszta Zs. (Eds.), Diplomás pályakövetés IV. Frissdiplomások 2010 (pp. 177-192). Budapest: Educatio Társadalmi Szolgáltató Nonprofit Kft. Felsőoktatási Osztály. (Graduates' Careers. Hungarian) 


\section{HERJ Hungarian Educational Research Journal Vol 6 (2016), No 1}

Kávássy, J. (2009). “The Hungarian model”: Hungary in the eighties in the eye of politicians and experts in the documents of the Hungarian Ministry for Foreign Affairs. Heller Farkas Papers, 7(1), 76-87.

Kim, J. (2011). Aspiration for global cultural capital in the stratified realm of global higher education: Why do Korean students go to US graduate schools? British Journal of Sociology of Education, 32(1), 109126.

Kiss, L. (2014). A tanulmányi célú nemzetközi hallgatói mobilitás alakulása Magyarországon. [Trends in study-driven international student mobility in Hungary] (pp. 135-159). In: A mozgás tere: A magyar felsőoktatás és a nemzetközi mobilitási folyamatok. Budapest: Campus Hungary. (Hungarian Higher Education and International Mobility. Hungarian)

Knight, J. (2004). Internationalization Remodeled: Definition, Approaches, and Rationales. Journal of Studies in International Education, 8 (1), 5-31.

Kozma, T. (2004). Kié az egyetem? [To Runs the University? Hungarian) Budapest: Új Mandátum Kiadó.

Kyvik, S., \& Ingvild, M. L. (1997). The exchange of knowledge: A small country in the international research community. Science Communication, 18(3), 238-264.

Langerné, R. M. (2009). A tanulói migráció és a munkapiac. [Student migration and the labor market]. In: Illés, S. (Ed.): Magyarország vonzásában. A Központi Statisztikai Hivatal Népességtudományi Kutatóintézetének kutatási jelentései 85. Budapest: Központi Statisztikai Hivatal Népességtudományi Kutatóintézet. (Reports of the Institute of Demographic Research 85. Hungarian)

Lightowler, C., Knight, C. 2013. Sustaining knowledge exchange and research impact in the social sciences and humanities: investing in knowledge broker roles in UK universities. Evidence \& Policy: A Journal of Research, Debate and Practice, 9, 3, 317-334.

Merton, R. K. (1968). Patterns of influence: Local and cosmopolitan influentials. In: Author, Social theory and social structure. New York: Free Press.

Meyer, M. (2010). The Rise of the Knowledge Broker. Science Communication, 32(1), 118-127.

Organisation for Economic Co-operation and Development (2013). Education at a Glance 2013: OECD indicators. Paris: OECD Publishing.

Perna, L. W., Orosz, K., \& Jumakulov, Z. (2015). Understanding the human capital benefits of a governmentfunded international scholarship program: An exploration of Kazakhstan's Bolashak program. International Journal of Educational Development, 40(1), 85-97.

Polyzoi, E., Cerna, M. (2001). A dynamic model of forces affecting the implementation of educational change in the Czech Republic. Comparative Education Review 45(1), 64-84.

Pusztai, G. \& Szabó, P. Cs. (2008). The Bologna Process as a Trojan horse. European Education 40(2), 85-103.

Pusztai, G. (2003). Assessing contemporary Hungarian society. Review of Sociology, 9(2), 1-15.

Pusztai, G. (2007). Új társadalmi kockázatok az európai tudástársadalomban és felsőoktatásban a szakemberekkel készült interjúk tükrében. [New social risks in the European Knowledge Society and Higher Education: Interviews with experts]. Retrieved from http://cherd.unideb.hu/NESOR\%20CHERD\%20Report\%202.0.pdf

Pusztai, G. (2015). Pathways to Success in Higher Education. Frankfurt am Main: Peter Lang. 
HERJ Hungarian Educational Research Journal Vol 6 (2016), No 1

Simmel, G. (1922). Conflict and the Web of Group Affiliations. Glencoe, USA: Free Press.

Statistical yearbook of education (2014) Ministry of Human Resources - Department of Statistics

Sverrisson, A. (2001). Translation networks, knowledge brokers and novelty construction: Pragmatic environmentalism in Sweden. Acta Sociologica, 44, 313-327.

Szemerszki, M. (2005). Külföldi hallgatók Magyarországon [Foreign students in Hungary]. Educatio , 14(2), 320-333.

Tót, É. (2005). Magyar hallgatók külföldön [Hungarian students abroad]. Educatio , 14(2), 302-319.

University of Debrecen (2014). Statistics: Foreign students at the University of Debrecen. Retrieved from http://www.unideb.hu/portal/sites/default/files/RH/2014.oktoberi_statisztikakulfoldi_hallgatok_orszagonkent.pdf

Viszt, E. (2004). A kutatók nemzetközi mobilitása [International mobility of researchers]. Magyar Tudomány, 2004(8), 302-319.

Webber, S. \& Liikanen, I. (eds) (2001). Education and Civic Culture in Postcommunist Countries. New York: Palgrave 